\title{
Differential stimulus coupling to dopamine and norepinephrine stores in rabbit carotid body type I cells
}

\author{
A. Gomez-Niño, B. Dinger, C. Gonzalez and S.J. Fidone \\ Department of Physiology, University of Utah School of Medicine, Salt Lake City, UT 84108 (U.S.A.)
}

(Accepted 1 May 1990)

Key words: Arterial chemoreceptor; Hypoxia; Nicotinic receptor; Chemotransmission; Transmitter release; Catecholamine

\begin{abstract}
Recent studies suggest that preneural type I (glomus) cells in the arterial chemoreceptor tissue of the carotid body act as primary transducer elements which respond to natural stimuli (low $\mathrm{O}_{2}, \mathrm{pH}$ or increased $\mathrm{CO}_{2}$ ) by releasing chemical transmitter agents capable of exciting the closely apposed afferent nerve terminals. These type I cells contain multiple putative transmitters, but the identity of the natural excitatory agents remains an unresolved problem in carotid body physiology. Characterization of putative transmitter involvement in the response to natural and pharmacological stimuli has therefore become fundamental to further understanding of chemotransmission in this organ. The present study demonstrates that a natural stimulus (hypoxia) evokes the release of dopamine (DA) and norepinephrine (NE) in approximate proportion to their unequal stores in rabbit carotid body (DA release $/ \mathrm{NE}$ release $=8.2)$. In contrast, nicotine $(100 \mu \mathrm{M})$, a cholinomimetic agent thought to act on the nicotinic receptors present on the type I cells, evokes the preferential release of NE (DA release/NE release $=0.17$ ). These findings suggest that distinct mechanisms are involved in a differential mobilization of these two catecholamines from the rabbit carotid body.
\end{abstract}

The chemosensory tissue of the mammalian carotid body consists of morphologically distinct type I (glomus) cells which lie in synaptic association with afferent nerve terminals of the carotid sinus nerve (CSN), a branch of the glossopharyngeal (IXth) cranial nerve. A fundamental issue in carotid body physiology concerns the role played by type I cells in chemotransduction and chemotransmission of natural and pharmacological stimuli (low $p \mathrm{O}_{2}, \mathrm{pH}$ or elevated $p \mathrm{CO}_{2}$; and cholinergic, peptidergic and catecholaminergic agents) ${ }^{11}$. With respect to chemotransduction, previous studies have demonstrated that type I cells respond to natural stimuli in vivo and in vitro in the absence of innervation ${ }^{10}$, thus implying that these cells may be good candidates for the role of chemosensory transducer in the carotid body. Moreover, recent reports have shown that type I cells possess a unique $\mathrm{O}_{2}$-sensitive potassium conductance, which is decreased by hypoxic stimuli within the physiological range ${ }^{21}$. With respect to chemotransmission between type I cells and sensory nerve terminals, a major problem remains how the multiple putative neurotransmitters found in type I cells (including biogenic amines and neuroactive peptides) are able to interact in the initiation and modulation of the chemosensory discharge of the CSN.

The putative transmitters present in highest concentrations in the carotid body are the catecholamines dopamine (DA) and norepinephrine (NE). While the precise role of DA remains uncertain, it is clear from previous studies with the rabbit carotid body that the synthesis and release of DA by type I cells is increased by natural stimuli ${ }^{10,11}$, and that dopaminergic $\left(D_{2}\right)$ receptors are present on CSN afferents ${ }^{5,24}$. In contrast, virtually nothing is known regarding the regulation of NE metabolism in the organ, and although its synthetic enzyme (dopamine $\beta$-hydroxylase; $\mathrm{DBH}$ ) is known to be present in type $I$ cells ${ }^{2,27}$, attempts to demonstrate NE/DBH sensitivity to chemoreceptor stimuli have until very recently met with little success ${ }^{14,15,26}$. Likewise, while the results of pharmacological experiments suggest that certain chemoreceptor responses by the carotid body may be mediated by $\beta$-adrenergic receptors ${ }^{12}$, a mechanism coupling specific stimuli to NE turnover and utilization has yet to be demonstrated.

In the present study, we have examined the release of $\left[{ }^{3} \mathrm{H}\right] \mathrm{DA}$ and $\left[{ }^{3} \mathrm{H}\right] \mathrm{NE}$ (synthesized from $\left[{ }^{3} \mathrm{H}\right]$ tyrosine) evoked by two classical chemoexcitatory agents ${ }^{11}$ (low $\mathrm{O}_{2}$ and nicotine) from rabbit carotid bodies superfused in vitro. While the data indicate that the release of both catecholamines is increased by these stimuli, it is clear that hypoxia evokes the release of $\left[{ }^{3} \mathrm{H}\right] \mathrm{DA}$ in proportion to its large content in the tissue, whereas nicotine produces a nearly selective release of $\left[{ }^{3} \mathrm{H}\right] \mathrm{NE}$. The results therefore suggest that functionally distinct mechanisms regulate the turnover of endogenous DA and NE in the

Correspondence: S.J. Fidone, Department of Physiology, University of Utah School of Medicine, 410 Chipeta Way, Research Park, Salt Lake City, UT 84108 , U.S.A. 
carotid body. Preliminary reports of these findings have appeared elsewhere ${ }^{14,15}$.

Rabbit carotid bodies were first chronically sympathectomized to eliminate the sympathetic (NE-containing) nerve terminals from the carotid body. Under pentobarbital anesthesia $(35 \mathrm{mg} / \mathrm{kg}$ ), superior cervical sympathetic ganglia were bilaterally excised from adult New Zealand white rabbits $10-14$ days prior to experimentation, at which time the animals were re-anesthetized and their carotid bodies surgically removed and cleaned of adjoining connective tissue in a bath of ice-cold modified Tyrode's solution (in $\mathrm{mM}: \mathrm{NaCl} 112$, $\mathrm{KCl} 4.7, \mathrm{CaCl}_{2} 2.2, \mathrm{MgCl}_{2} 1.1$, sodium glutamate 42 , HEPES buffer 5 , glucose $5.6, \mathrm{pH}=7.42$ ) equilibrated with $100 \% \mathrm{O}_{2}$. The tissues were pooled and incubated for $2 \mathrm{~h}$, as previously described ${ }^{9}$, in media containing $\left[{ }^{3} \mathrm{H}\right]$ tyrosine $(20-40 \mathrm{Ci} / \mathrm{mmol} ; 20-25 \mu \mathrm{M}$; Amersham) plus ascorbic acid $(100 \mu \mathrm{M})$ and tyrosine hydroxylase cofactor $\left(6-\mathrm{MPH}_{4} ; 50 \mu \mathrm{M}\right)$. Following incubation, carotid bodies were separated into groups of 2-4 and washed for $90 \mathrm{~min}$ (fresh media every $30 \mathrm{~min}$ ) in standard scintillation vials containing modified Tyrode's solution equilibrated with $100 \% \mathrm{O}_{2}$. Catecholamine $(\mathrm{CA})$ release was determined utilizing radiolabeling techniques in conjunction with HPLC separation of DA from NE, and was assessed during stimulus cycles which each consisted of sequential control $\left(100 \% \mathrm{O}_{2}\right.$-media), stimulus (low $\mathrm{O}_{2}$ or nicotine-containing media) and post-stimulus (100\% $\mathrm{O}_{2}$-media) periods. Similar results to those reported here were obtained when a bicarbonate- $\mathrm{CO}_{2}\left(\begin{array}{lll}95 \% & \mathrm{O}_{2} / 5 \%\end{array}\right.$ $\left.\mathrm{CO}_{2}, \mathrm{pH}=7.42\right)$ buffer was used in place of the HEPES $-\mathrm{O}_{2}\left(100 \% \mathrm{O}_{2}\right.$ or $\left.10 \% \mathrm{O}_{2} / 90 \% \mathrm{~N}_{2}\right)$ buffer; i.e., release profiles were qualitatively the same, and quantitatively within $10 \%$ of each other. Superfusates were collected in vials containing ascorbic acid $(10 \mathrm{mM})$, plus acetic acid $(4 \mathrm{M})$, and stored overnight $\left(4^{\circ} \mathrm{C}\right) .\left[{ }^{3} \mathrm{H}\right] \mathrm{DA}$, $\left[{ }^{3} \mathrm{H}\right]$ DOPAC and $\left[{ }^{3} \mathrm{H}\right] \mathrm{NE}$ were eluted from alumina columns (see ref. 10) with $1 \mathrm{~N}$ perchloric acid, and the labeled products combined with unlabeled NE, DA and DOPAC prior to HPLC separation on a C-18 reverse phase column (Rainin) in phosphate-buffered mobile phase. Sample aliquots spiked with 3,4-dihydroxymandelic acid (DOMA) and 3-methoxy-4-hydroxy-phenylglycol (MHPG) were chromatographed separately to quantify these NE metabolites. CA was detected electrochemically with an ESA Coulochem (Model 5100A; 5021 conditioning cell; 5011 analytical cell) in the reductive mode. Peaks of interest were collected automatically with a Gilson Model 202 fraction collector for subsequent counting in a Packard Model 1500 scintillation spectrometer.

The data presented in Fig. 1 (top) show total $\left[{ }^{3} \mathrm{H}\right] \mathrm{CA}$ release from an experiment in which carotid bodies were exposed to two stimulus cycles; the first cycle contained media equilibrated with $10 \% \quad \mathrm{O}_{2}$, the second cycle contained $100 \% \mathrm{O}_{2}$ equilibrated media along with 100 $\mu \mathrm{M}$ nicotine, which in preliminary dose-response experiments had proven to evoke an intermediate amount of $\left[{ }^{3} \mathrm{H}\right] \mathrm{CA}$ release. Between stimulus cycles the tissue was washed for $30 \mathrm{~min}$ with two changes of $100 \% \mathrm{O}_{2}$ equilibrium media. We consistently observed a different time course of $\mathrm{CA}$ release for low $\mathrm{O}_{2}$ vs nicotine stimulation. CA release evoked by low $\mathrm{O}_{2}$ persisted into the first post-stimulus period, whereas nicotine-evoked release ended abruptly after the 5 min stimulus period. Reversal of the stimulus order resulted in similar relative patterns of $\mathrm{CA}$ release by low $\mathrm{O}_{2}$ and nicotine. The
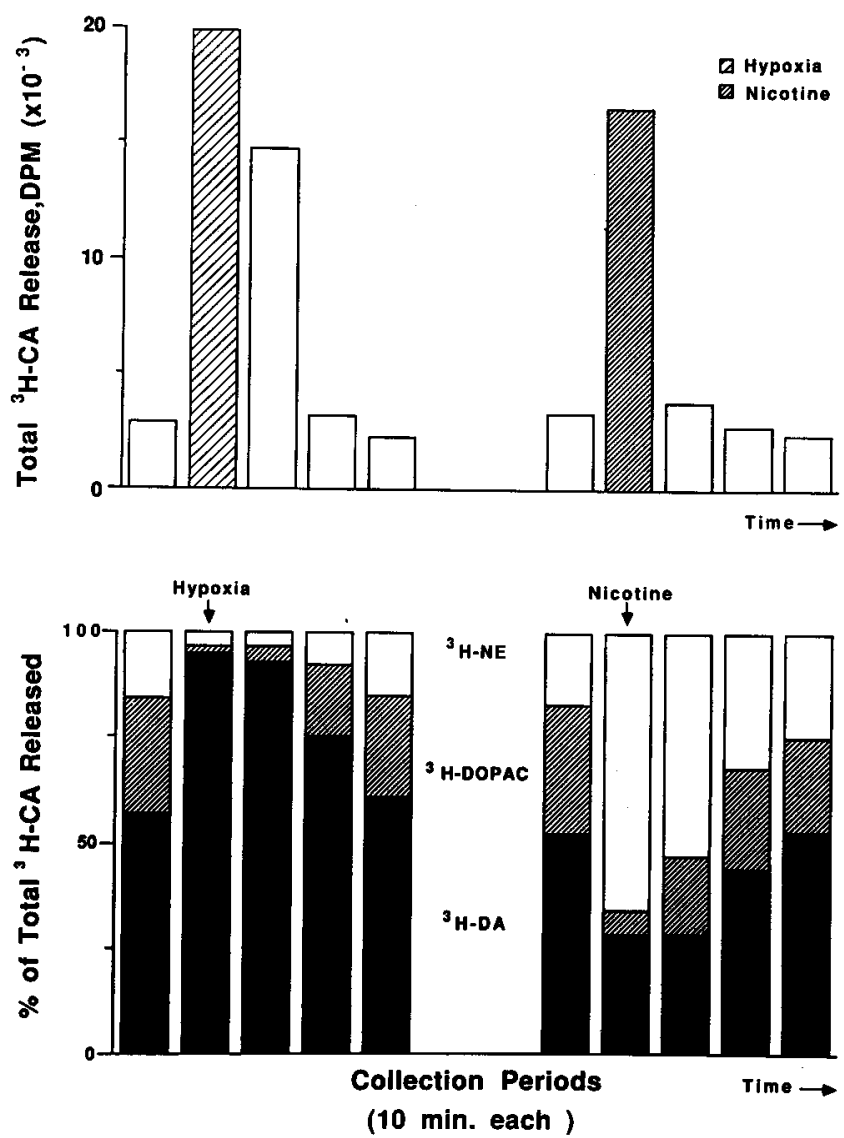

Fig. 1. Basal and stimulus-evoked $\left[{ }^{3} \mathrm{H}\right]$ catecholamine $\left(\left[{ }^{3} \mathrm{H}\right] \mathrm{CA}\right)$ release from 4 sympathectomized rabbit carotid bodies superfused in vitro. The superfusion media were replaced at $10 \mathrm{~min}$ intervals, except during stimulation (low $\mathrm{O}_{2}$ or nicotine) which lasted $5 \mathrm{~min}$; for comparison purposes, release during these periods was multiplied by 2 . Basal release was evaluated immediately prior to stimulation in media equilibrated with $100 \% \mathrm{O}_{2}$. The carotid bodies were stimulated with media equilibrated with $10 \% \mathrm{O}_{2}$ or with media equilibrated with $100 \% \mathrm{O}_{2}$ and containing $100 \mu \mathrm{M}$ nicotine, and release was evaluated through 3 post-stimulus periods. Between stimulus cycles the tissue was washed for $2 \times 15 \mathrm{~min}$ in $100 \% \mathrm{O}_{2}$ media. Upper panel: total $\left[{ }^{3} \mathrm{H}\right] \mathrm{CA}$ released; lower panel: profile of ${ }^{3} \mathrm{H}-\mathrm{NE}$ (open bars), ${ }^{3} \mathrm{H}-\mathrm{DOPAC}$ (cross-hatched bars) and $\left[{ }^{3} \mathrm{H}\right] \mathrm{DA}$ (filled bars) release determined by HPLC and scintillation analysis. 
reasons for this difference in time course of release is not known, but receptor desensitization by nicotine $e^{20,22}$ must be considered a possible explanation for future experiments addressing this issue. The receptor specificity of the nicotine effect was established in control experiments which showed that mecamylamide $(100 \mu \mathrm{M})$, hexamethonium $(100 \mu \mathrm{M})$ and $(+)$-tubocurarine $(50 \mu \mathrm{M})$ blocked more than $95 \%$ of the nicotine-evoked release of $\left[{ }^{3} \mathrm{H}\right] \mathrm{CA}$.

Fig. 1 (bottom) shows the relative proportions of DA and $\mathrm{NE}$ released during the two stimulus cycles described above. The content of $\left[{ }^{3} \mathrm{H}\right] \mathrm{NE},\left[{ }^{3} \mathrm{H}\right] \mathrm{DA}$ and $\left[{ }^{3} \mathrm{H}\right]-$ DOPAC are expressed as a percent of the total $\left[{ }^{3} \mathrm{H}\right] \mathrm{CA}$ $\left(\left[{ }^{3} \mathrm{H}\right] \mathrm{NE}+\left[{ }^{3} \mathrm{H}\right] \mathrm{DA}+\left[{ }^{3} \mathrm{H}\right] \mathrm{DOPAC}\right)$ released in each sample. In most instances the NE metabolites DOMA and MHPG amounted to only $4-5 \%$ of the released $\left[{ }^{3} \mathrm{H}\right] \mathrm{CA}$, and they never exceeded $11 \%$ of the total $\left[{ }^{3} \mathrm{H}\right] \mathrm{CA}$ release either under resting conditions or in response to hypoxia or nicotine. It is apparent from the data that the relative proportions of $\left[{ }^{3} \mathrm{H}\right] \mathrm{DA}$ and $\left[{ }^{3} \mathrm{H}\right] \mathrm{NE}$ release are different for the low $\mathrm{O}_{2}$ vs the nicotine stimulus. Exposure to low $\mathrm{O}_{2}$-media primarily evoked release of $\left[{ }^{3} \mathrm{H}\right] \mathrm{DA}$, while $\left[{ }^{3} \mathrm{H}\right] \mathrm{NE}$ dominated the profile of nicotine-evoked release. These differing patterns of release are unlikely due to non-specific effects of the stimuli, because exposure of carotid bodies to high $\mathrm{K}^{+}$ $(75 \mathrm{mM})$ produced a release profile which closely reflects the relative $\left[{ }^{3} \mathrm{H}\right] \mathrm{DA} /\left[{ }^{3} \mathrm{H}\right] \mathrm{NE}$ content in the organ (not shown).

Data from multiple release experiments utilizing low $\mathrm{O}_{2}$ and nicotine as secretogogues are presented in Table I. $\left[\begin{array}{ll}3 \\ H\end{array}\right] \mathrm{CA}$ release in control $\left(100 \% \mathrm{O}_{2}\right)$ superfusion media during the $10 \mathrm{~min}$ period immediately prior to stimulation consisted of $16.9 \% \quad\left[{ }^{3} \mathrm{H}\right] \mathrm{NE}$ and $83.1 \%$ $\left[{ }^{3} \mathrm{H}\right] \mathrm{DA}+\left[{ }^{3} \mathrm{H}\right]$ DOPAC. Release during superfusion with $10 \% \mathrm{O}_{2}$-media was comprised of $98.1 \%\left[{ }^{3} \mathrm{H}\right] \mathrm{DA}+$ $\left[{ }^{3} \mathrm{H}\right]$ DOPAC. Although only a small portion of the evoked release was due to $\left[{ }^{3} \mathrm{H}\right] \mathrm{NE}$, its concentration in the superfusion media was nonetheless approximately doubled by the hypoxic stimulus. However, it must be considered that the scintillation data alone may not accurately reflect the relative amounts of $\mathrm{NE}$ and $\mathrm{DA}$ released in these experiments, because the specific activity of these two CA (and their metabolites) in the tissue may be different. Indeed, the specific activity of DA in the tissue after the experiment was usually 2-5 times greater than that for $\mathrm{NE}$, due to the slower turnover and synthesis of NE by the carotid body 9 . Conversion of the fractional radiolabelled content released to the physiologically relevant parameter of absolute amount released, requires an estimate of the specific activities of the released $\left[{ }^{3} \mathrm{H}\right] \mathrm{NE}$ and $\left[{ }^{3} \mathrm{H}\right] \mathrm{DA}$. Experiments in our laboratory addressed this point for the release of $\mathrm{DA} /\left[^{3} \mathrm{H}\right] \mathrm{DA}$ evoked by hypoxia and elevated $\mathrm{K}^{+}(60 \mathrm{mM}$; ref. 3$)$. The results showed that the specific activity of released $\left[{ }^{3} \mathrm{H}\right] \mathrm{DA}$ (plus $\left[{ }^{3} \mathrm{H}\right] \mathrm{DOPAC}$ ) was very similar to that of the $\left[{ }^{3} \mathrm{H}\right] \mathrm{DA}$ remaining in the tissue. Thus, it appears that during the $90 \mathrm{~min}$ wash period before collection of samples, the newly synthesized $\left[{ }^{3} \mathrm{H}\right] \mathrm{DA}$ equilibrates with the endogenous unlabeled DA pool in our experiments. These results are in agreement with other studies describing the incorporation of newly synthesized $\mathrm{NE}$ into the endogenous $\mathrm{CA}$ pool in sympathetic nerve terminals in the spleen $^{13,18}$. Consequently, we used the specific activity data for $\mathrm{DA} /\left[{ }^{3} \mathrm{H}\right] \mathrm{DA}$ and $\mathrm{NE} /\left[{ }^{3} \mathrm{H}\right] \mathrm{NE}$ content from stimulated carotid bodies in order to calculate the total stimulusevoked release of NE and DA, and these results are presented in Table II. The data show that conversion from $\mathrm{dpm}$ released/mg tissue, to absolute amount released ( $\mathrm{pmol} / \mathrm{mg}$ tissue) confirms the predominance of DA release by hypoxia and actually exaggerates the predominance of NE release by nicotine. The absolute amounts of NE and DA released in response to hypoxia were approximately in proportion to the relative content of these two $\mathrm{CA}$ in the tissue, whereas in response to nicotine the nearly 5 -fold preference for NE release reflects a markedly disproportionate mobilization of $\mathrm{NE}$ vs DA stores in these sympathectomized carotid bodies. The data additionally show that basal release consisted of

TABLE I

Release of radiolabeled CA from sympathectomized rabbit carotid bodies measured in media equilibrated with $100 \% \mathrm{O}_{2}(\mathrm{control}), 10 \% \mathrm{O} \mathrm{O}_{2}$ or $100 \%$ $\mathrm{O}_{2}$-media containing $100 \mu \mathrm{m}$ nicotine

Values are means \pm S.E.M. with numbers of samples in brackets.

\begin{tabular}{|c|c|c|c|c|}
\hline & \multicolumn{2}{|l|}{ dpm/mg tissue } & \multicolumn{2}{|l|}{$\%$ of total $C A$} \\
\hline & $\left.{ }^{3} H\right] N E$ & {$\left[^{3} H\right] D O P A C+\left[{ }^{3} H\right] D A$} & $\left.P^{3} H\right] N E$ & $\left.\left[{ }^{3} H\right] D O P A C+l^{3} H\right] D A$ \\
\hline $\begin{array}{l}\text { Control (basal) } \\
10 \% \mathrm{O}_{2} \\
100 \mu \mathrm{M} \text { nicotine }\end{array}$ & $\begin{array}{c}242 \pm 37(16) \\
538 \pm 77^{*}(11) \\
4223 \pm 78^{*}(6)\end{array}$ & $\begin{array}{r}1193 \pm 191^{*} \\
28138 \pm 7946^{*}(11) \\
2747 \pm 410^{*}\end{array}$ & $\begin{array}{r}16.9 \% \pm 2.6 \% \\
1.9 \% \pm 0.3 \% \\
60.1 \% \pm 1.1 \%\end{array}$ & $\begin{array}{l}83.1 \% \pm 13.3 \% \\
98.1 \% \pm 27.7 \% \\
39.9 \% \pm 5.9 \%\end{array}$ \\
\hline
\end{tabular}

${ }^{*} P<0.001$ vs basal release. 


\section{TABLE II}

Absolute amounts of $C A$ released (pmollmg tissue) calculated from measurements of the specific activity of $\left.D A / I^{3} H\right] D A$ and $N E /\left[^{3} H\right] N E$ in stimulated carotid bodies

Values are means \pm S.E.M. with numbers of samples in brackets.

\begin{tabular}{|c|c|c|c|c|}
\hline & \multicolumn{2}{|l|}{ pmol/mg tissue } & \multicolumn{2}{|l|}{$\%$ of total $C A$} \\
\hline & $N E$ & $\left.D O P A C+\Gamma^{3} H\right] D A$ & $N E$ & $D O P A C+D A$ \\
\hline $\begin{array}{l}\text { Control (basal) } \\
10 \% \mathrm{O}_{2} \\
100 \mu \mathrm{M}\end{array}$ & $\begin{array}{l}0.227 \pm 0.03(16) \\
0.833 \pm 0.16^{*}(11) \\
3.143 \pm 0.49^{*}(6)\end{array}$ & $\begin{array}{l}0.224 \pm 0.04 \\
6.851 \pm 1.936^{*}(11) \\
0.544 \pm 0.09^{*}\end{array}$ & $\begin{array}{l}50.3 \% \pm 6.7 \% \\
10.8 \% \pm 2.1 \% \\
85.2 \% \pm 13.3 \%\end{array}$ & $\begin{array}{l}49.7 \% \pm 8.9 \% \\
89.2 \% \pm 25.2 \% \\
14.8 \% \pm 2.4 \%\end{array}$ \\
\hline
\end{tabular}

${ }^{*} P \leqslant 0.001$ vs basal release.

approximately equal portions of DA and NE.

Our findings demonstrate that nicotine and hypoxia differentially mobilize NE vs DA from carotid body CA stores. However, there is not complete selectivity by these stimuli, because hypoxia consistently evoked the release of small amounts of $\left[{ }^{3} \mathrm{H}\right] \mathrm{NE}$, while $\left[{ }^{3} \mathrm{H}\right] \mathrm{DA}$ was released at relatively low levels in response to nicotine (see Table I). In this regard, it may be important to consider that release-promoting events might be occurring secondary to the initial stimulus-induced release; for example, the activation of $\beta$-adrenergic receptors in the carotid body has been reported to evoke DA outflow ${ }^{25}$, and consequently a possible sequence of events might involve first a selective nicotine-induced release of $\mathrm{NE}$, followed by $\beta$-receptor activation and the subsequent release of DA. In addition, preliminary experiments which examined the effects of combined stimulation with nicotine and hypoxia showed that the total $\left[{ }^{3} \mathrm{H}\right] \mathrm{CA}$ release was larger than the sum of the release evoked by each condition, suggesting interesting interactive effects of these stimuli.

The observation that hypoxia and nicotine evoke the release of DA and NE from the carotid body in distinctly different proportions suggests that these stimuli activate diverse mechanisms for mobilizing these two CA from the type I cells of this chemosensory organ. Although it has been conjectured that separate dopaminergic and noradrenergic cells may exist in the carotid body 1 , $2,4,16,17,23$, recent immunocytochemical studies have shown that virtually all type I cells contain both tyrosine hydroxylase $(\mathrm{TH})$, the rate limiting enzyme for $\mathrm{CA}$ synthesis, and dopamine- $\beta$-hydroxylase $(\mathrm{D} \beta \mathrm{H})$, the synthetic enzyme for NE production ${ }^{2,27}$. While these studies suggest a ubiquitous distribution for DA and NE amongst type I cells, the levels of immunocytochemical reaction product for $\mathrm{D} \beta \mathrm{H}$ reported in these studies indicate that some cells may contain much more NE than others. This possibility, coupled with the observation by Chen and Yates $^{1}$ that specific $\alpha$-bungarotoxin binding sites in the carotid body are restricted to a subgroup of type I cells (distinguished on the basis of dense-core vesicle size; refs. 16,23 ), suggests the possibility that the observed preferential release of NE over DA might arise from the selective distribution of nicotinic receptors on cells which contain relatively high levels of NE. Alternatively, type I cells in the carotid body may represent a homogeneous population with respect to their content of DA and NE and their sensitivity to nicotine. Different proportions of CA release would then be achieved through the selective mobilization of dense-cored vesicles containing either mostly DA or NE. The available data are equivocal with respect to the cellular mechanisms involved in the observed differential release of $\mathrm{CA}$, and although recent immunocytochemical studies of $\mathrm{TH}$ and $\mathrm{D} \beta \mathrm{H}$ have provided useful information in this regard, it must also be recognized that the demonstrated presence of a transmitter's synthetic enzymes do not necessarily signal the presence of the transmitter ${ }^{19}$.

Finally, the involvement of nicotinic receptors in the response to type I cells to chemoreceptor stimuli (natural and pharmacological) suggests a role for $\mathrm{ACh}$ in chemosensation. More than 20 years ago, Eyzaguirre and Zapata $^{8}$ demonstrated that anoxia or electrical stimulation of the carotid body evoked the release of an ACh-like substance from the organ. Early neurochemical and autoradiographic studies placed ACh in the type I cells $^{11}$, and this prospect was firmly established by recent immunocytochemical studies localizing to these cells the synthetic enzyme for $\mathrm{ACh}$, choline acetyltransferase $(\mathrm{ChAT})^{28}$. Ligand binding studies using $\alpha$-bungarotoxin and quinuclidinylbenzylate (QNB) have further demonstrated that cholinergic receptors are located on type I cells $^{6,7}$. The current demonstration that nicotinic receptors evoke the preferential release of NE from the carotid body emphasizes the need for further experimentation regarding the physiological roles played by $\mathrm{ACh}$ and $\mathrm{NE}$ in the carotid body.

Supported by USPHS Grants NS12636 and NS07938, and DGICYT PB86-0325 (Spain). 
1 Chen, I.L. and Yates, R.D., Two types of glomus cell in the rat carotid body as revealed by $\alpha$-bungarotoxin binding, $J$. Neurocytol., 13 (1984) 281-302.

2 Chen, I.L., Hansen, J.T. and Yates, R.D., Dopamine $\beta$ hydroxylase-like immunoreactivity in the rat and cat carotid body: a light and electron microscopic study, J. Neurocytol., 14 (1985) 131-144.

3 Cheng, G.-F., Dinger, B. and Fidone, S.J., The release of labeled and unlabeled catecholamines from rabbit carotid body, Soc. Neurosci. Abstr., 13 (1987) 1111.

4 Chistie, D.S. and Hansen, J.T., Cytochemical evidence for the existence of norepinephrine-containing glomus cells in the rat carotid body, J. Neurocytol., 12 (1983) 1041-1053.

5 Dinger, B., Gonzalez, C., Yoshizaki, K. and Fidone, S., $\left[{ }^{3} \mathrm{H}\right]$ Spiroperidol binding in normal and denervated carotid bodies, Neurosci. Lett., 21 (1981) 51-55.

6 Dinger, B., Gonzalez, C., Yoshizaki, K. and Fidone, S.J., Localization and function of cat carotid body nicotinic receptors, Brain Research, 339 (1985) 295-304.

7 Dinger, B., Hirano, T. and Fidone, S.J., Autoradiographic localization of muscarinic receptors in rabbit carotid body, Brain Research, 367 (1986) 328-331.

8 Eyzaguirre, C. and Zapata, P., The release of acetylcholine from carotid body tissues. Further study on the effects of acetylcholine and cholinergic blocking agents on the chemosensory discharge, J. Physiol., 195 (1968) 589-607.

9 Fidone, S. and Gonzalez, C., Catecholamine synthesis in rabbit carotid body in vitro, J. Physiol., 333 (1982) 69-79.

10 Fidone, S.J., Gonzalez, C. and Yoshizaki, K., Effects of low oxygen on the release of dopamine from the rabbit carotid body in vitro, J. Physiol., 333 (1982) 93-110.

11 Fidone, S.J. and Gonzalez, C., Initiation and control of chemoreceptor activity in the carotid body. In J.G. Widdicombe (Ed.), Handbook of Physiology, The Respiratory System II, Am. Physiol. Soc., Washington, DC, 1986, pp. 247-312.

12 Folgering, H., Ponte, J. and Sadig, T., Adrenergic mechanisms and chemoreception in the carotid body of the cat and rabbit, $J$. Physiol., 325 (1982) 1-21.

13 Gewirtz, G.P. and Kopin, J.J., Effect of intermittent nerve stimulation on norepinephrine synthesis and mobilization in the perfused cat's spleen, J. Pharmacol. Exp. Ther., 175 (1970) $514-520$.

14 Gomez-Niño, A., Gonzalez, C., Dinger, B. and Fidone, S., Dopamine and norepinephrine release from the rabbit carotid body in vitro. Diverse effects of low $\mathrm{O}_{2}$ versus nicotine, $F A S E B$ J., 2 (1988) A1733.

15 Gomez-Niño, A., Cheng, G.-F., Yoshizaki, K., Gonzalez, C., Dinger, B. and Fidone, S., Regulation of the release of dopamine and norepinephrine from rabbit carotid body. In $\mathrm{C}$. Eyzaguirre, S. Fidone, R. Fitzgerald, S. Lahiri and D. McDon- ald (Eds.), Proceedings of the Ninth International Symposium on Arterial Chemoreception, Springer, New York, in press.

16 Hellström, S., Morphometric studies of dense cored vesicles in type I cells of carotid body, J. Neurocytol., 4 (1975) 77-86.

17 Hellström, S. and Koslow, S.H., Biogenic amines in carotid body of adult and infant rats, a gas chromatographic-mass spectrometric assay, Acta Physiol. Scand., 93 (1975) 540-547.

18 Kopin, I.J., Breese, G.R., Krauss, K.R. and Weise, V.K., Selective release of newly synthesized norepinephrine from the cat spleen during sympathetic nerve stimulation, J. Pharmacol. Exp. Ther., 161 (1968) 271-278.

19 Landis, S.C., Jackson, P.C., Fredien, J.R. and Thibault, J., Catecholaminergic properties of cholinergic I neurons and synapses in adult rat ciliary ganglion, $j$ Neurosci., 7 (1987) 3574-3587.

20 Livett, B.G., Peptide modulation of adrenal chromaffin cell secretion. In K. Rosenheck and P.J. Lelkes (Eds.), StimulusSecretion Coupling in Chromaffin Cells, Vol. II, CRC Press, Boca Raton, FL, 1987, pp. 117-150.

21 López-Barneo, J., López-López, J.R., Ureña, J. and González, C., Chemotransduction in the carotid body: $\mathrm{K}^{+}$current modulated by $\mathrm{PO}_{2}$ in type I chemoreceptor cells, Science, 241 (1988) 580-582.

22 Marley, P.D., Desensitization of the nicotinic secretion, response of adrenal chromaffin cells, Trends Pharmacol. Sci., 9 (1988) 102-107.

23 McDonald, D.M. and Mitchell, R.A., The innervation of glomus cells, ganglion cells and blood vessels in the rat carotid body: a quantitative ultrastructural analysis, J. Neurocytol., 4 (1975) $177-230$

24 Mir, A.K., McQueen, D.S., Pallot, D.J. and Nahorski, S.R., Direct biochemical and neuropharmacological identification of dopamine $\mathrm{D}_{2}$-receptors in the rabbit carotid body, Brain Research, 291 (1984) 273-283.

25 Perez-García, T., Almaraz, L. and González, C., Modulation of the secretory response in carotid body chemoreceptor cells by adenylate cyclase activating agents, Soc. Neurosci. Abstr., 14 (1988) 80.

26 Shaw, K., Montague, W. and Pallot, D.J., Biochemical studies on the release of catecholamines from the rat carotid body in vitro, Biochim. Biophys. Acta, 1013 (1989) 42-46.

27 Wang, Z.-Z., Dinger, B., Fidone, S. and Stensaas, L.J., Co-existence of tyrosine-hydroxylase and dopamine- $\beta$-hydroxylase immunoreactivities in type I glomus cells of the cat carotid body, Soc. Neurosci. Abstr., 14 (1988) 113.

28 Wang, Z.-Z., Stensaas, L.J., Dinger, B. and Fidone, S.J., Immunocytochemical localization of choline acetyltransferase in the carotid body of the cat and rabbit, Brain Research, 498 (1989) 131-134. 